\title{
DESTINACIJSKI MENADŽMENT U FUNKCIJI RAZVOJA KULTURNOG TURIZMA KONTINENTALNE HRVATSKE - PRIMJER DESTINACIJE KRIŽEVCI
}

\author{
Tea Golja \\ Sveučilište Jurja Dobrile u Puli \\ tea.golja@unipu.hr \\ Romana Lekić \\ Edward Bernays \\ romana.lekic@bernays.hr
}

\section{Sažetak}

Konkurentnost turističke destinacije definira se kao njezina sposobnost da kreira i sustavno integrira turističke proizvode, odnosno usluge i doživljaje više dodane vrijednosti. Razvoj destinacijskog menadžmenta i strateško pozicioniranje kroz odabrane turističke proizvode, odnosno doživljaje te upravljanje kako lancem vrijednosti s jedne strane, tako i iskustvom posjetitelja s druge, su uvjeti bez kojih se niti jedna destinacija ne može razviti. Turistički proizvod se formira prvenstveno na destinacijskoj, a dijelom i na regionalno razini, čime regije i (u novije vrijeme) destinacije postaju sredstvo razmjene, odnosno ono što se na turističkom tržištu nudi i prodaje. Stoga proces upravljanja turističkim destinacijama, iako u velikoj mjeri virtualan i nestandardiziran, danas postaje ne samo važnim nego i nužnim poslom i pretpostavkom za konkurentski i održivi rast turizma destinacije - bez obzira na njenu veličinu.

Svrha ovog istraživanja je utvrditi mogućnosti i prilike za razvoj proizvoda kulturnog turizma u Križevcima. Provedena su istraživanja u 
destinaciji i to fokus grupe i anketno ispitivanje. Cilj je dvojaki. Primarno želi se potaknuti osmišljavanje inovativnih proizvoda kulturnog turizma temeljeno na resursnoj osnovi Križevaca. Sekundarno, želi se ukazati na prilike za unapređenje, posebice na važnost i ulogu destinacijskog menadžmenta u razvoju faktora atraktivnosti koji snažno utječu na destinacijsku konkurentnost. U radu se uspostavlja poveznica između teorijskog određenja koncepta kulturnog turizma i destinacijskog menadžmenta te rezultata empirijskih istraživanja. Rezultati ukazuju da lokalno stanovništvo prepoznaju resursnu osnovu Križevaca kao snažan potencijal za razvoj proizvoda kulturnog turizma. No, evidentan je jaz između sadašnje ponude doživljaja kulturnog turizma i mogućnosti koje destinacija ima s obzirom na svoju resursnu osnovu. Zbog toga autori predlažu nekoliko inovativnih proizvoda kulturnog turizma kojima se može obogatiti ponuda ove turističke destinacije. Rezultati istraživanja koristit će planerima razvoja turizma ove destinacije, te ostalim interesnim dionicima koji žele doprinijeti razvoju proizvoda književnog i manifestacijskog turizma, ali i onima koji se žele uključiti u kreativnu interpretaciju nematerijalne kulturne baštine Križevaca.

Ključne riječi: destinacijski menadžment, kulturni turizam, književni turizam, storytelling, manifestacijski turizam, Križevci.

\section{Uvod}

Nezaustavljiva globalizacija, dinamična konkurencija i suvremene potrebe turista osnovni su poticaji jačanju konkurentske pozicije turističke destinacije na sve zahtjevnijem turističkom tržištu (Vodeb, 2012; Dwyer, 2015). Društvene promjene, digitalizacija i transformacija turizma nameću potrebu za drugačijim upravljanjem razvojem turizma, ali i načinom kreiranja turističkih proizvoda i doživljaja u turističkoj destinaciji (Hristov, 2015; Dredge, et. al., 2018; González-Reverté, 2019; UNWTO, 2019). Zasigurno jedan od bitnih elemenata osiguravanja atraktivnosti i konkurentnosti turističke destinacije leži u destinacijskom menadžmentu koji, ne samo da (ko)kreira turističke doživljaje i proizvode koji će dodati vrijednost turističkoj destinaciji na odgovoran način, već i 
strateški planira te razvija turizam u destinaciji u suradnji i koordinacijom različitih interesnih dionika (Binkhorst i Den Dekker, 2009; Selen i Ogulin, 2015; Slivar, 2018). Nerijetko se radi o dionicima različita interesa, ali usmjerenima jednom zajedničkom cilju - očuvati konkurentnost turističke destinacije na sve dinamičnijem turističkom tržištu kako bi se osigurala dugoročna održivost poslovne aktivnosti. Analiza i mjerenje konkurentnosti turističke destinacije područje je interesa mnogih autora koji zasebno izučavaju set indikatora, između ostalih i važnost destinacijskog menadžmenta (Crouch i Ritchi, 2000; Dwyer i Kim, 2010, Tigu, 2012; Bosnić, Stanišić i Tubić, 2014; Capone, 2015). U koordinaciji takvog procesa i slaganju kockica integriranog destinacijskog proizvoda i doživljaja za turiste, osiguravanje kvalitete života lokalnog stanovništva, očuvanje lokalnog identiteta i kulture nezaobilazno i prioritetno je. Ovakvu je ulogu i cilj sustava destinacijskog menadžmenta egzaktno propisao i Zakon o turističkim zajednicama i promicanju hrvatskog turizma (Narodne novine, 52/19 i 42/20).

Križevci su jedan od najstarijih gradova sjeverozapadne Hrvatske. Život ljudi u križevačkom kraju može se pratiti unatrag 5000 godina. Taj podatak potvrđuju brojni arheološki nalazi iz mlađeg kamenog i metalnog doba. Na širem križevačkom području (bivša općina Križevci) pronađeno je 81 arheološko nalazište. Područje Grada Križevaca (kao i područje čitave Koprivničko-križevačke županije) prema krajobraznoj regionalizaciji pripada području Panonske Hrvatske. Zauzima prostor dviju različitih geografskih cjelina: Bilogorsko-moslavački prostor i Sjeverozapadna Hrvatska. Područje Grada Križevaca i okolne regije obiluje bogatom kulturnom baštinom - materijalnom i nematerijalnom, koja čini dobru bazu na kojoj se može temeljiti, kako komparativna, tako i snažna konkurentska prednost ove turističke destinacije. Upravo zbog navedenog polazi se od temeljne hipoteze da Križevci, kao Kontinentalna Hrvatska destinacija, u svrhu osnaživanja konkurentnosti i razvoja održivog turizma, moraju svoju priliku prepoznati u turizmu posebnih interesa, a posebice kulturnom turizmu.

Svrha ovog istraživanja je utvrditi prilike za razvoj određenih proizvoda kulturnog turizma u Križevcima, a temeljeno na provedenim primarnim istraživanjima među kojima se izdvajaju fokus grupe i anketno 
ispitivanje o resursnoj osnovi destinacije. Cilj je dvojaki. Primarno želi se potaknuti osmišljavanje inovativnih proizvoda kulturnog turizma. Sekundarno, želi se ukazati na prilike za unapređenje, posebice važnost i ulogu destinacijskog menadžmenta u razvoju faktora atraktivnosti koji snažno utječu na destinacijsku konkurentnost. U radu je uspostavljena poveznica između teorijskog određenja koncepta kulturnog turizma i destinacijskog menadžmenta te rezultata empirijskih istraživanja.

Rezultati ovog istraživanja imaju aplikativnu vrijednost jer se svi ponuđeni proizvodi kulturnog turizma mogu izravno i vrlo brzo implementirati u turističku ponudu, a time je značajno i obogatiti. Riječ je o turističkim proizvodima kojima se stvara dodana vrijednost u destinaciji. Za navedeno je ključna suradnja interesnih dionika, proaktivni angažman i umrežavanje te koordinacija kroz sustav destinacijskog menadžmenta.

\section{Kulturni turizam}

Kultura kao pojam ima različito značenje u različitim znanstvenim područjima kao što su filozofija, sociologija, primijenjena umjetnost, arhitektura, medicina. Podložna je stalnim promjenama koje donosi vrijeme u kojem nastaje. Definirati je, unatoč tomu, možemo kao skladnu sintezu čovjekova povijesnog stvaralaštva koja obuhvaća njegovo znanstveno, filozofsko i umjetničko umijeće, osjetilnost i iskustvo. Kulturu sačinjavaju dva međusobno povezana područja: materijalna kultura (sredstva za proizvodnju i ostale materijalne tvorevine) i duhovna kultura (ukupnost rezultata znanosti, umjetnosti i filozofije, morala i običaja) (Milanja, 2012, 13). Odnosno, kultura može biti opipljiva - muzeji, galerije, dvorci, izložbe, koncerti, kazališta, ali i neopipljiva - običaji, tradicija. Univerzalna deklaracija Organizacije Ujedinjenih naroda za obrazovanje, znanost i kulturu (UNESCO) o kulturnoj raznolikosti u članku 7. navodi da svaka kreativnost potiče iz kulturnih tradicija, a širi se u kontaktu s drugim kulturama (UNESCO, 2001). Upravo je zbog toga važno sačuvati kulturno naslijeđe, vrednovati ga i prenijeti na druge generacije. Jedan od načina valorizacije kulture zasigurno je i turizam, odnosno jedan posebni oblik turizma - kulturni turizam. Početak kulturnog turizma javlja se još 80-ih godina prošlog stoljeća. Počeo se razvijati u doba masovnog turizma, što se 
možda i ne može povezati zato jer kulturni turizam ne „trpi” masovnost, ali prema istraživanjima svako se putovanje može okarakterizirati kao kulturno jer putnik namjerno ili slučajno na putovanju dolazi do novih saznanja, informacija te upoznaje novu kulturu s kojom dolazi u kontakt. U povijesti je putovanje bilo privilegij ljudi veće platežne moći, te su ljudi uglavnom putovali zbog vjere ili ratovanja, ali svakako su prvenstveni motivi bili upoznavanje novih kultura koje nude određene destinacije i obrazovanje. U današnje vrijeme rast potražnje za kulturnim turizmom sve je veći. Na međunarodnoj razini kulturni turizam zauzima oko $40 \%$ udjela u ukupnim međunarodnim turističkim kretanjima (UNWTO, 2018), a u Europi je taj udio gotovo identičan ili čak i viši (European Commission, 2020a). Danas su ljudi obrazovaniji, bolje platežne moći, nemaju dovoljno slobodnog vremena što implicira da ga moraju iskoristiti na najbolji način, željni su novih spoznaja, učenja te postaje sve jasnije da je došlo do zasićenja turizma zasnovanog na temeljnom proizvodu „sunca i mora”. Traže se novi sadržaji, inovativni i edukativni doživljaji u turizmu koji će biti prava protuteža stresnoj svakodnevici i užurbanosti suvremenog turiste - još uvijek X generaciji, ali sve više i onoj Milenijskoj, a sutra Iphone generaciji (Mahika, 2011; Slivar and Golja, 2015; Moscardo, 2015; Yousaf, Amin i Santos, 2018). Kulturni turizam spada u tzv. „slow tourism" ili spori i odgovorni posebni oblik turizma (Callot, 2013; Moira, Mylonopoulos i Koundoudaki, 2017; EUROPA NOSTRA, 2019; HTHIC, 2020).

Izazovno je definirati kulturni turizam i kulturnog turista jer kultura i turizam znače razlite stvari različitih ljudima (McKercher i Du Cros, 2003). Pod definicijom kulturnog turizma, između ostalog, možemo podrazumijevati putovanje osoba do specifičnih kulturnih atrakcija kao što su povijesna mjesta, umjetničke i kulturne manifestacije, posjeti izložbama i predstavama izvan mjesta stalnog boravka, s namjerom skupljanja novih informacija i iskustava kako bi zadovoljili svoje kulturne potrebe. Posjetitelji dobivaju uvid u novi i drugačiji način materijalnog i nematerijalnog življenja. Posjeti osoba motivirani su u cijelosti ili djelomično do određene razine zanimanjem za povijest, umjetnost, naslijeđe, stil života, lokaliteta, regije ili institucije. Pojam kulturnog turizma općenito se primjenjuje na putovanja koja uključuju posjet kulturnim resursima bez obzira na 
inicijalnu motivaciju. Csapo (2012) smatra da kulturni turizam u sebi sadrži vrlo različite oblike turizma objedinjene pod „istom kapom“, a koji tako mogu uključivati baštinu (materijalnu i nematerijalnu), kulturne tematske rute (duhovne, gastronomske, jezične i sl.), gradski kulturni turizam, tradicijski/etno turizam, turizam događanja i festivala, vjerski turizam, kreativni turizam (izvedbena umjetnost, obrti, zanati i sl.) Naočigled jednostavno, no definicija kulturnog turizma, prema mišljenju McKerchera i Du Crosa (2002), ima jako puno, gotovo koliko ima i različitih vrsta kulturnih turista. Silberger (1995) tako identificira četiri vrste kulturnih turista: (1) oni motivirani kulturnim turizmom; (2) oni koji su djelomično motivirani kulturnim turizmom; (3) oni kojima je kultura sporedna u obilasku neke destinacije i (4) slučajni kulturni turisti. Isti autor navodi i petu skupinu turista i lokalnih stanovnika koji ni pod kojim uvjetima ne žele posjetiti niti jednu turističku atrakciju. Njih ne smatra dijelom tržišta kulturnog turizma. McKercher (2002) stoga sugerira da se definicija kulturnog turista može razviti uzimajući u obzir dva elementa: osnovne razloge putovanja (motivacija) neke osobe i razinu iskustva u destinaciji. Kulturni turizam bavi se cijelim rasponom ljudskog stvaralaštva, običajima, naslijeđem, kulturnim aktivnostima. Takav turizam ujedno stvara partnerstvo između različitih sadržaja, ali se ujedno i uklapa i u način života mjesta. (Klarić et. al., 2011) Tablica u nastavku prikazuje mikroniše kulturnog turizma. 
Tablica 1: Mikroniše u kulturnom turizmu

\begin{tabular}{|l|l|l|}
\hline $\begin{array}{l}\text { Unutar područja } \\
\text { materijalne baštine }\end{array}$ & $\begin{array}{l}\text { Unutar područja } \\
\text { nematerijalne baštine }\end{array}$ & $\begin{array}{l}\text { Unutar područja } \\
\text { kreativnog turizma } \\
\text { vezanog za } \\
\text { nematerijalnu baštinu }\end{array}$ \\
\hline $\begin{array}{l}\text { ruralni/urbani } \\
\text { turizam }\end{array}$ & \\
$\square$ povijesni turizam & $\square$ turizam događanja & $\square$ fototurizam \\
$\square$ arheološki turizam & $\square$ festivalski turizam \\
$\square$ etno i tradicijski & $\square$ edukativni/školski & $\square$ slikarski/likovni \\
turizam & turizam & $\square$ literarni turizam \\
$\square$ sakralni turizam & $\square$ kazališni turizam \\
$\square$ umjetnički turizam & $\square$ genealoški turizam & $\square$ muzički turizam \\
$\square$ izložbe & $\square$ vjerski turizam & $\square$ didaktički turizam \\
$\square$ spomenički turizam & $\square$ volonterski turizam & $\square$ istraživački turizam \\
$\square$ eko-kulturni & $\square$ kontemplativni & $\square$ memorijalni turizam \\
turizam & turizam & $\square$ kulinarski turizam \\
$\square$ industrijski turizam & & \\
& & \\
\hline
\end{tabular}

Izvor: Klarić, et. al. (2011). Muzeji i turizam. Djelovanje muzeja kao dionika kulturnog turizma. Priručnik. Zagreb: Muzej suvremene umjetnosti, str. 8.

Jedna od najkvalitetnijih i najzanimljivijih odlika kulturnog turizma njegova je autentičnost i jedinstvenost. Naime, na svijetu ne postoje dva ista dvorca, iste crkve, isti spomenici, običaji. Naprotiv, svaki je za sebe jedinstven i poseban. Odluka turista hoće li ili neće kupiti određeni turistički proizvod i odlučiti se za neki doživljaj, ovisi o tome koliko ga on smatra istinskim, koliko ga i na koji način doživljava. Autentičnost je danas kompleksan proces posredništva i pregovaranja između različitih očekivanja turista, ponude destinacije te kulturne politike lokalnih zajednica. Kulturni turizam i kulturna baština pružaju i čuvaju naslijeđe za buduće naraštaje. Kako pojam kulturnog turizma sjedinjuje u sebi pojmove kulture i turizma, a upravo kultura i kulturna baština doprinose atraktivnosti određene turističke destinacije, često su važan preduvjet turističkog odabira.

Turizam čini 10\% europskog BDP-a. U turizmu je zaposleno 12 milijuna ljudi što čini 9\% ukupnog broja zaposlenih u Europi (European 
Commission, 2018). Europski kreativni i kulturni sektori doprinose s 5,3\% bruto dodane vrijednosti EU-e i čine oko 4\% BDP-a. Nadalje, osiguravaju oko 12 milijuna radnih mjesta, što čini $7 \%$ ukupnog broj zaposlenih u EU-u i treći su najveći sektor u EU prema broju zaposlenih (European Commission, 2020b). U okviru Europske unije ima oko 200.000 zaštićenih urbanih cjelina i 2,5 milijuna građevina pod zaštitom. To je izniman potencijal, pa je sasvim logično što je kultura postala glavni pokretač turističke potražnje i rasta, tako da su istodobno resursi kulturne baštine stavljeni u središte urbanih i ruralnih razvojnih strategija (Christou 2005). Stoga ne čudi da je kulturni turizam, kao spoj sektora kulture i turizma, sve popularniji i jedan od oblika turizma za kojega se predviđa da će doživjeti najveći rast u budućnosti. Zbog jedinstvene kulturne baštine, Europa je vodeća destinacija kulturnog turizma u svijetu i takav oblik turizma snažno stimulira razvoj inovativnih turističkih proizvoda prilagođenih potrebama suvremenog turiste. Osnovni razlozi rasta popularnosti kulturnog turizma u Europi, sukladno rezultatima projekta PICTURE su (Rainette, Dumont i Drdacky, 2007): rasprostranjenost i demokratizacija kulture od sredine 20. st. koja je dovela do proširenja koncepta kulture; promjena uzorka turizma - jasna je tendencija prema kraćim boravcima i većoj fragmentaciji praznika koja povećavaju kratke posjete većinom turizma kulturnog i urbanog predznaka, pristupačnost jeftinih (engl. low-cost) prijevoznika, demografski faktori kao što je starenje stanovništva, snažna aktivnost lokalnih, nacionalnih i europskih vlasti koji prepoznaju turizam kao izvor dobiti i otvaranja radnih mjesta, nova svijest o zaštiti i pristupačnosti prirodne i kulturne baštine te rast „sofisticiranih“ turista koji su u potrazi za raznolikim i neotkrivenim sadržajima. U brojnim europskim poveljama i dokumentima kulturni je turizam prepoznat kao jedan od ključnih pokretača europskog ekonomskog rasta i razvoja. On igra vitalnu ulogu u jačanju većeg razumijevanja bogatstva i raznolikosti regionalnih kultura Europe i dubljeg poštivanja zajedničke europske baštine. Kulturni je turizam jedan od najznačajnijih izraza kulturne razmjene između ljudi u Europskoj uniji i jedan od najvrjednijih instrumenata interkulturnog dijaloga.

Kulturni turizam sve se više razvija i u Hrvatskoj, no nije dovoljno afirmiran i valoriziran. Tržište još uvijek nedovoljno prepoznaje bogatu 
kulturnu baštinu Hrvatske. Ono što se mora istaknuti jest da kulturni turizam zaokuplja pažnju stručnjaka i profesionalaca kako u turizmu, tako i u kulturi, a i mladih koji se sve više odlučuju na dodatno obrazovanje u području kulture i turizma što je evidentno posljednjih godina atraktivnošću interdisciplinarnih studijskih programa koji kombiniraju kulturu i turizam. Akcijskim planom razvoja kulturnog turizma u Hrvatskoj su se stvorili preduvjeti za sustavni razvoj ovog posebnog oblika turizma 2015. godine (Institut za turizam, 2015). No, primarni motivi dolaska gostiju u Hrvatsku i dalje su uživanje u suncu i moru neovisno o iznimno bogatoj kulturnoj baštini Hrvatske (Institut za turizam, 2018). Nadalje, valja reći da, turisti koji dolaze, najviše vremena provode i posjećuju područje Jadranske Hrvatske, dok Kontinentalna Hrvatska i dalje ostaje slabo posjećena regija. Ne postoje recentniji podatci o profilu kulturnih turista od rezultata istraživanja Instituta za turizam objavljenog 2008. godine (Institut za turizam, 2008). Prema istom Izvješću, glavni posjetitelji kulturnih atrakcija i događanja u Hrvatskoj su oni srednje (47\%) i mlađe (30\%) životne dobi, fakultetski su obrazovani (38\%) ili sa završenom višom školom (24\%). Većina (55\%) ima ukupna mjesečna primanja kućanstva u rasponu od 7300 do 21.900 kn (1000 do 3000 eura). Među kulturnim turistima prevladavaju inozemni posjetitelji (62\%), a pojedinačno značajniju skupinu čine posjetitelji iz Italije (15\%), Njemačke (14\%), Francuske (9\%) te Velike Britanije (9\%). Među domaćim, najbrojniji su posjetitelji iz matične županije ili okolnih županija. Glavnina posjetitelja već je posjetila ili planira posjetiti svjetovne (65\%) i sakralne (64\%) znamenitosti, muzeje i galerije (59\%) i kulturna događanja (42\%). Oko trećine pokazuje interes za glazbeno-scenske predstave i tematske rute/ putove. Veliki udio (60\%) posjetitelja izražava zanimanje za sudjelovanje u kreativnim radionicama, među kojima su najpopularniji gastronomski tečajevi (24\%), sudjelovanje u berbama (23\%) te arheološka iskapanja (21\%). Prosječna dnevna potrošnja posjetitelja kulturnih atrakcija i događanja na višednevnim putovanjima iznosi 45 eura. S obzirom na vrstu posjećene atrakcije/događanja, najbolji su potrošači posjetitelji muzeja i galerija. $\mathrm{Na}$ višednevnim putovanjima oni troše u prosjeku 57 eura, a na jednodnevnim 35 eura. 


\section{Destinacijski menadžment}

Kultura je jedan od bitnijih čimbenika podizanja atraktivnosti i konkurentnosti turističke destinacije. No, sinergija kulture i turizma se neće dogoditi bez da se ona potakne, da se razvija i da se njome upravlja. Upravo zbog toga, značajnu ulogu u implementaciji kulturne baštine $u$ proizvode kulturnog turizma ima destinacijski menadžment.

Zadatak je destinacijskog menadžmenta pronaći odgovarajuću ravnotežu između kompetitivnog vanjskog okruženja, društvenih i ekonomskih ciljeva, očuvanja prirodnih resursa, zadržavanja privlačnosti destinacije i građenja njezine reputacije s jedne strane te ekonomskog doprinosa turizma destinaciji i blagostanja lokalne zajednice i njezinih stanovnika s druge. Po definiciji je to holistički i odgovorni pristup upravljanju turizmom u destinaciji. Ritchie i Crouch (2003) smatraju da je pred destinacijskim menadžmentom izazov upravljanja nizom komponenti na način da se osigura ekonomska profitabilnost istovremeno izbjegavajući stvaranje negativnih posljedica po čimbenike koji su utjecali na stvaranje destinacijske konkurentske pozicije. Destinacijski menadžment je koordinirana aktivnost kojom se kontrolira ekonomska, socio-kulturna i okolišna dimenzija na specifičnom turističkom prostoru (Destinet, 2020), odnosno destinaciji. Zanimljivo je i stajalište Francha i Martinia (2002) koji definiraju destinacijski menadžment kao strateške, organizacijske i operativne odluke koje se donose kako bi se upravljalo ne samo procesom definiranja, promocije i komercijalizacije turističkih proizvoda, već i turističkim prometom u destinaciji (posjetiteljima) koji nužno mora biti uravnotežen, održiv i dostatan da zadovolji ekonomske potrebe lokalnih interesnih dionika u destinaciji.

Iako je nekada tradicionalna funkcija destinacijske menadžment organizacije bila promocija destinacije i sustava turističkih proizvoda, njezina je uloga tokom vremena evoluirala. Danas je pred destinacijskim menadžment organizacijama puno više zadataka i uloga, a promocija i prodaje destinacije samo je jedna od njih. Morrison, Bruen, i Anderson (1998) razlikuju pet primarnih funkcija destinacijske menadžment organizacije: 
- pokretač ekonomije - doprinosi generiranju prihoda, novim zapošljavanjima, generiranju poreznih prihoda kojima se doprinosi diversifikaciji lokalne ekonomije

- komunikator u zajednici - komunikator destinacijskog imidža, atrakcija i raznih objekata prema ciljnom tržištu

- koordinator turizma - osigurava jasan fokus istovremeno naglašavajući važnost smanjenja fragmentacije industrije i dijeljenja koristi od turizma

- „kvazi“ javni predstavnik - dodaje legitimitet industriji i brine o sigurnosti pojedinačnih i grupni posjetitelja

- „kreator“ društvenog ponosa - kroz djelovanje usmjereno na osnaživanje kvalitete života za lokalne stanovnike i posjetitelje.

Presenza i Sheehan (2005) isto tako na vrlo zanimljiv način prikazuju dvije temeljne uloge destinacijske menadžment organizacije koje se i danas mogu lako prepoznati u poslovnom modelu i rezultatima onih uspješnih destinacijskih menadžment organizacija:

1. Eksterni marketing destinacije - poduzima sve osnovne operacijske odnosno taktičke marketinške aktivnosti

2. Interni razvoj destinacije - poduzima sve ostale aktivnosti (marketing isključen) koje osiguravaju razvoj turizma u destinaciji (krizni menadžment, razvoj ljudskih resursa, osiguravanje financijskih resursa, pomno upravljanje destinacijskim resursima, osnaživanje iskustva posjetitelja, koordinacija interesnih dionika u destinaciji, informativni centri, istraživanje i analiza podataka).

Prema gore navedenome, uspješna destinacijska menadžment organizacija mora učinkovito upravljati svim aspektima integriranog destinacijskog proizvoda/doživljaja - ne samo marketingom i promocijom. Upravljati se mora i svim lokalnim resursima - naslijeđenim prirodnim i kulturnim, zatim onim kreiranim i potpornim od smještajnih kapaciteta, raznih destinacijskih aktivnosti i događanja, turističkih atrakcija, pa sve do prijevoza i osiguravanja bolje pristupačnosti destinaciji i dobrih odnosa s ključnim emitivnim tržištima i lokalnom zajednicom. Zbog 
toga se sugerira da se destinacijska menadžment organizacija organizira po modelu zajedničke suradnje javnog sektora i ostalih interesnih dionika u turizmu (realni i treći sektor) uz kvalitetno i etičko upravljanje. No, diljem svijeta, različite su organizacijske strukture i modeli u primjeni. Odabrana struktura destinacijske menadžment organizacije i kontekst $\mathrm{u}$ kakvom djeluje implicira njezine mogućnosti financiranja. Ono što ipak valja istaknuti je da destinacijska menadžment organizacija ne kontrolira aktivnosti svojih partnera, već objedinjuje postojeće resurse i iskustva različitih partnera uz određeni stupanj neovisnosti i objektivnosti, a sve s ciljem navigacije u „održivi model razvoja turizma“. U principu se može razlikovati nekoliko osnovnih kategorija destinacijskih menadžment organizacija, a hrvatski Zakon o turističkim zajednicama i promicanju hrvatskog turizma upravo tako i prepoznaje sustav organizacije turističkih zajednica. To su: nacionalna destinacijska menadžment organizacija, regionalna destinacijska menadžment organizacija i lokalna destinacijska menadžment organizacija.

U nastavku se slikovito prikazuje transformacija uloge i funkcija destinacijskog menadžmenta.

Shema 1: Od tradicionalne funkcije destinacijskog menadžmenta do integriranog destinacijskog menadžmenta

MARKETING I

PROMOCIJA

(traditionalna uloga)
STRATEŠKO

PLANIRANJE,

KOORDINACIJA I

MENADŽMENT,
INTEGRIRANI \&

ODRŽIVI DESTINACIJSKI

MENADŽMENT (turizam nakon koronakrize)

Izvor: autori

Održivi razvoj turizma pretpostavlja model koji se bazira na održivom upravljanju, održivom menadžmentu i održivom marketing turističke destinacije (Golja i Slivar, 2014). Buhalis (2000) destinacije 
smatra amalgamima različitih turističkih proizvoda koje nude integrirano iskustvo svojim potrošačima. No, na destinacijskom menadžmentu je prepoznati potencijale svoje resursne osnove (naslijeđene i kreirane), zatim svih ostalih potpornih resursa i čimbenika razvoja turizama u destinaciji, a sve kako bi uspješno razvijao konkurentski destinacijski proizvod. Zbog toga je važno u proces razvoja destinacijskog proizvoda uključiti interesne dionike i „poslušati“ mišljenje i prijedloge lokalne zajednice koja mora svaki proizvod prihvatiti da bi on, u konačnici, bio uspješan. Neuspješan će biti razvoj bilo kojeg oblika turističkog proizvoda kojeg lokalno stanovništvo ne želi ili ne može prihvatiti. Zbog toga je suradnja ovdje jako važna.

\section{Empirijsko istraživanje: Potencijali razvoja kulturnog turizma Križevaca i destinacijski menadžment kao ključan čimbenik uspjeha}

Tijekom veljače i ožujka 2020. godine provedene su fokus grupe s ukupno 23 sudionika - različitih interesnih skupina s područja Grada Križevaca.

Tijekom travnja i svibnja 2020. godine provedeno je anketno ispitivanje na području Grada Križevaca i okoline. Anketni upitnik distribuiran je na način da je poziv objavljen na mrežnim stranicama Grada Križevaca, Turističke zajednice Grada Križevaca i direktno je upućen svim sudionicima fokus grupe s kojima se provodilo posebno istraživanje s ciljem analiziranja konkurentnosti turističke destinacije (23 sudionika). Anketni je upitnik bio dostupan i na društvenim mrežama navedenih organizacija. Do sredine svibnja prikupljeno je ukupno 155 povratnih odgovora. Tako se pristupilo obradi prikupljenih rezultata istraživanja na navedenom uzorku. Demografski profil ispitanika je bio različit, od mladih, preko stanovnika srednje životne dobi pa i do onih starijih.

$\mathrm{Za}$ ispitivanje stavova o važnosti kulturnih resursa turističke destinacije i trenutnom zadovoljstvu načinom korištenja istih u turističke svrhe koristila se Likertova skala od 1 - 5 (1 - najmanja važnost/značaj; 5 - iznimno visoka važnost/značaj). U nastavku slijedi grafički prikaz dobivenih rezultata. 
Grafikon 1: Procjena važnosti odabranih kulturnih resursa Križevaca

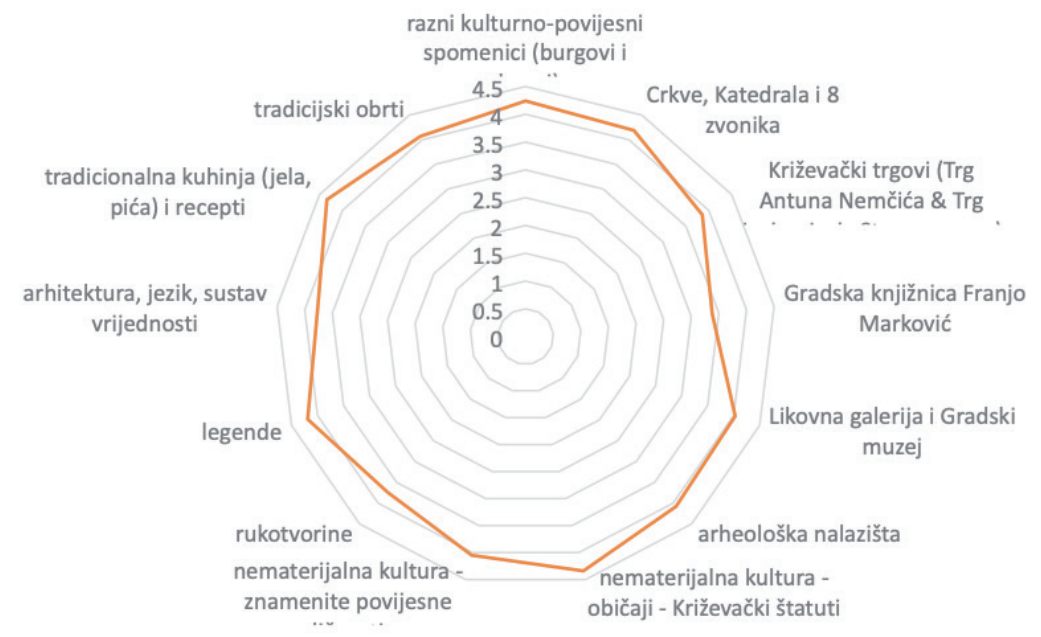

Izvor: obrada autora

Analiza atrakcijskog potencijala ukazuje na to da su Križevci bogati kulturnim resursima. Valja istaknuti da cijelo područje zapravo karakterizira ljepota krajolika, očuvana sela i bogata kulturna baština i kulturna ponuda (događanja). Križevci, sukladno prirodnim, geografskim i prostornim obilježjima, broju stanovnika, socio-kulturnom okruženju, raspolažu s resursnom osnovom pogodnom za razvitak cjelogodišnjeg turizma i matrice različitih proizvoda održivog turizma, a posebice kulturnog turizma. Ispitanici su prepoznali kulturne resurse Križevaca i okolice kao vrlo važne i pridali su im visoku prosječnu ocjenu - 4 . Ispitanici pridaju vrlo visoku važnost upravo nematerijalnoj kulturi Križevaca izdvojivši Križevačke štatute, tradicionalnu kuhinju (jela, pića) i recepte, te razne kulturno-povijesne spomenike, burgove i dvorce kao najvažnije kulturne resurse Križevaca i okolice. 
Grafikon u nastavku prikazuje trenutno zadovoljstvo korištenjem kulturnih resursa u turističke svrhe.

Grafikon 2: Procjena zadovoljstva korištenjem kulturnih resursa u turističke svrhe

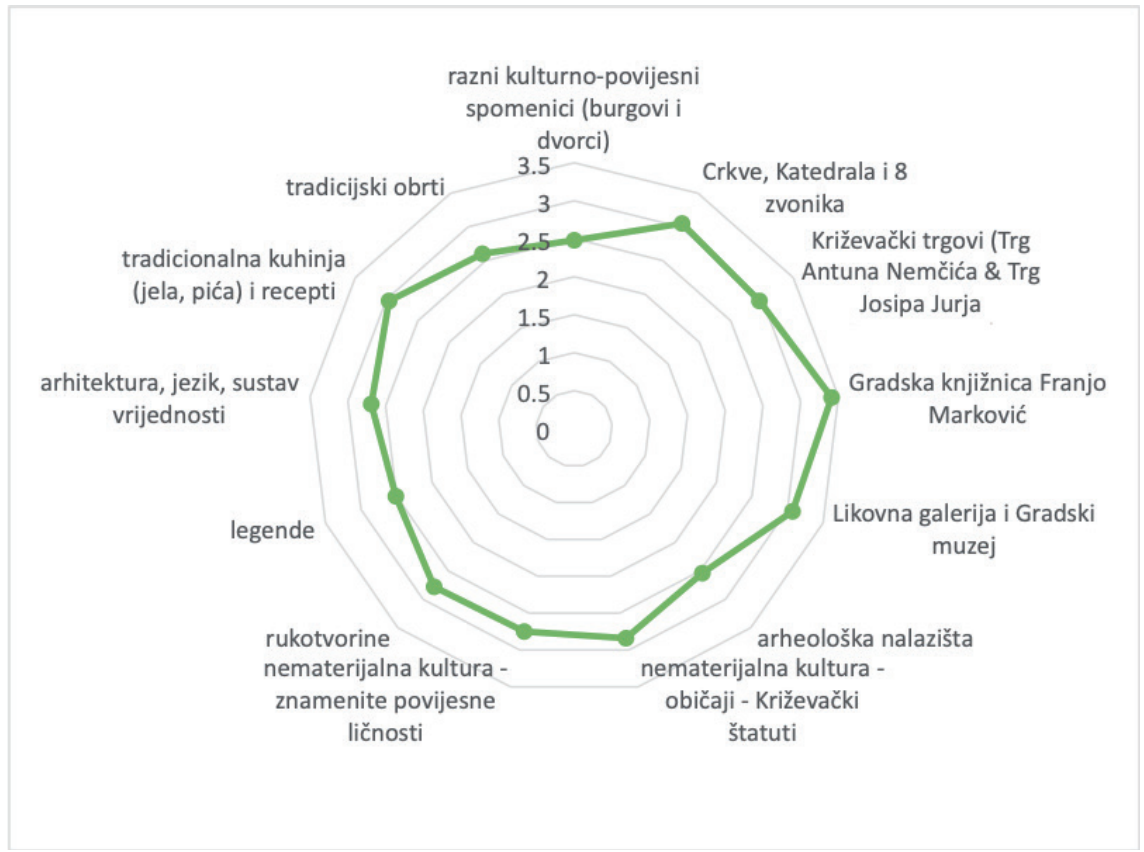

Izvor: obrada autora

S druge strane, kada se promotri zadovoljstvo s naslijeđenim kulturnim resursima, ispitanici su istome pridali nižu ocjenu - 2,82. Ispitanicu su najmanje zadovoljni načinom na koji se u turističke svrhe koriste kulturno-povijesni spomenici i ovdje se uočava najveći jaz u odnosu na visoku važnost koja se istima pridaje. Nadalje, ispitanicu su izrazito nezadovoljni načinom na kojim se koriste legende kao nematerijalna kultura u promociji i kreiranju turističkih proizvoda/doživljaja. Jednako tako, ispitanici vide potencijal u arheološkim nalazištima, dok se veliko odstupanje uočava između važnosti koju istima pridaju i trenutnom zadovoljstvu korištenja arheoloških nalazišta u turističke svrhe.

Evidentno je zabilježeno negativno odstupanje (prosječno -1,18) što ukazuje da se naslijeđeni kulturni resursi nedovoljno dobro koriste u svrhu turizma. Negativno odstupanje ukazuje da ispitanici ocjenjuju Križevce 
manje konkurentnima od usporednih destinacija (Koprivnica i Varaždin) sagledavajući kulturne resurse kao važne determinante koje određuju konkurentnost turističke destinacije.

Kako bi razvoj turističkog proizvoda bio učinkovit, i u konačnici, dugoročno održiv, nužno je uspostaviti učinkoviti destinacijski menadžment u Križevcima. Rezultati istraživanja ukazali su da Križevci nisu razvili sustav participativnog destinacijskog upravljanja. Nedostaje razvojni pristup koji olakšava transformaciju ruralnog prostora $\mathrm{u}$ integriranu turističku destinaciju. U tijeku je izrada Strategija razvoja turizma. S obzirom na navedeno ne čudi da su ispitanici ukazali na nisku razinu zadovoljstva trenutnim modelom razvoja turizma u Križevcima. Visoko je negativno odstupanje između zadovoljstva i željenog stanja. Za uspjeh ja važno imati jasnu viziju u koju vjeruju svi interesni dionici i u koju povjerenje ima lokalna zajednica. Ispitivanje je pokazalo da je vrlo visoka važnost pridana upravo jasnoj viziji i jasnim strateškim smjernicama razvoja turizma Križevaca, ali je zadovoljstvo trenutnim vrlo nisko. Implementacija zahtjeva horizontalno i vertikalno povezivanje. Od Turističke zajednice se nužno očekuje povezivanje i usmjeravanje turističke ponude uz aktivnu promociju turističkih proizvoda, a posebice organizaciju i razvoj proizvoda kulturnog turizma za kojeg postoje razvojni potencijali i visoka očekivanja. Ispitanici su ocijenili aktivnosti destinacijske menadžment organizacije (DMO ili turističke zajednice), politike razvoja turizma i sustav upravljanja okolišem kao atribute iznimno visoka značaja. Pritom su aktivnostima destinacijske menadžment organizacije umjereno zadovoljni. Jednako su tako umjereno zadovoljni turističkim politikama destinacije i ekološkim politikama koje se provede u destinaciji.

$\mathrm{U}$ nastavku se prikazuje percepcija ispitanike o određenim čimbenicima destinacijskog menadžmenta spomenutim u tekstu iznad. 
Grafikon 3: Destinacijski menadžment - čimbenici uspjeha

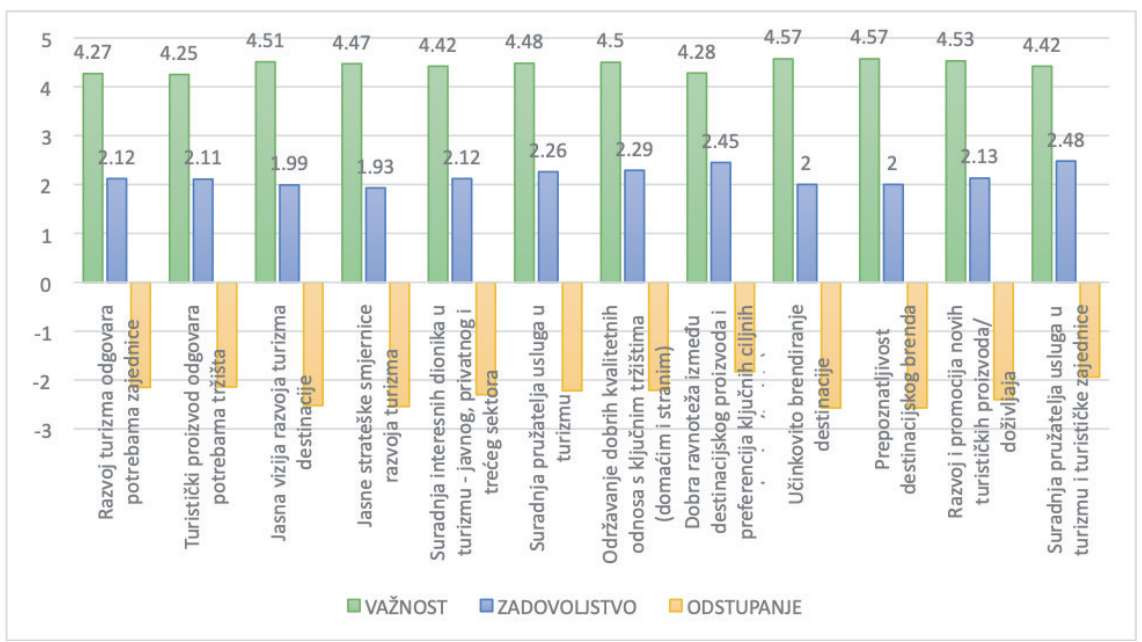

Izvor: obrada autora

Iz gornjeg grafikona može se uočiti vrlo visoka važnost koju ispitanici pridaju razvoju i promociji novih turističkih proizvoda/ doživljaja. No, veliki je jaz uočen između onoga što smatraju važnim i onoga što trenutno percipiraju kao realnim stanjem u destinaciji. Uočiti se također može da razvoj turizma danas ne odgovara potrebama stanovnika, a ispitanici ocjenjuju da turistički proizvod ne odgovara potrebama tržišta i novim trendovima što implicira nužno promjenu paradigme i uspostavu kvalitetnog upravljanja razvojem destinacijskog proizvoda. Održivi put razvoja turizma za Grad Križevce je upravo sudioničko upravljanje koje pretpostavlja uključivanje građana, sudjelovanje, umrežavanje i horizontalnu podjelu odgovornosti. Građani prestaju biti samo publika koja pasivno prima turističke i kulturne sadržaje koje je producirao „netko drugi“, već postaju aktivni kreatori turističkih i kulturnih politika, a turizam postaje agens povezivanja u zajednici i time doprinosi i održivom razvoju i kvaliteti života svih građana. Glavne prepreke implementaciji sudioničkog upravljanja u turizmu ustanovljene su kroz zatvorenost institucija i inertnost građana pojedinaca koji ne vide „širu sliku“ i mogućnosti koje turizam, a posebno implementiranje postojećih kulturnih atrakcija te spajanje kulturnih i sportskih aktivnosti, manifestacija i okolne regije sa turizmom nudi. 


\section{Prijedlozi inovativnih proizvoda kulturnog turizma}

Temeljem analize resursne osnove, provedenih fokus grupa i anketnog ispitivanja, autori procjenjuju potencijale za razvoj kulturnog turizma u Križevcima te predlažu određene proizvode kulturnog turizma s kojima se može napraviti iskorak u odnosu na konkurentske destinacije.

Tablica 2: Potencijal razvoja kulturnog turizma Križevaca i čimbenici uspjeha proizvoda

\begin{tabular}{|c|c|}
\hline proizvod & kulturni turizam \\
\hline tržišni potencijal & $\square$ visok \\
\hline $\begin{array}{l}\text { potencijal za razvoj } \\
\text { proizvoda }\end{array}$ & $\square$ visok \\
\hline potencijalna tržišta & $\begin{array}{l}\square \text { lokalno, strani turisti } \\
\square \text { regionalno } \\
\square \text { porodice s djecom } \\
\square \text { stariji posjetitelji } \\
\square \text { školske ekskurzije }\end{array}$ \\
\hline $\begin{array}{l}\text { čimbenici uspjeha } \\
\text { proizvoda }\end{array}$ & $\begin{array}{l}\square \text { destinacijski menadžment i destinacijska } \\
\text { menadžment organizacija } \\
\square \text { uređeni prilazi najznačajnijim atrakcijama, } \\
\text { minimalno turistička signalizacija, interpretacijska } \\
\text { ploča i promotivni/info pamflet } \\
\square \text { jednako tretirati i građevine koje se obnavljaju te } \\
\text { arheološke lokalitete (interpretaciju preusmjeriti na } \\
\text { priču o propadanju, zaštiti i restauraciji) } \\
\square \text { za događanja sastaviti portfelj atrakcija kako bi se } \\
\text { izbjeglo tematsko dupliranje i vremensko } \\
\text { preplitanje u projektnoj regiji } \\
\square \text { odabirom tema osnažiti ostale proizvode/teme - } \\
\text { poticati one na temu gastronomije, lokalnih } \\
\text { običaja, eko-festivali i sl. (folklorne smotre ostaviti } \\
\text { u domeni amaterskog kulturnog stvaralaštva) } \\
\square \text { uvezati prostorno disperzirane kulturne atrakcije } \\
\text { tematskom rutom biciklima, pješice } \\
\square \text { povezati tematsku rutu s komercijalnim turističkim } \\
\text { sadržajima kako bi se posjetiteljima osigurao } \\
\text { komfor, a turističkom sektoru ekonomska dobit }\end{array}$ \\
\hline
\end{tabular}


U nastavku slijede prijedlozi inovativnih proizvoda kulturnog turizma.

\section{Priče i pričanje / Storytelling}

Pripovijedanje se može opisati kao inspirativni prijenos doživljene priče o slobodnom vremenu u kojem pleme, obitelj ili pojedinac može ojačati osjećaj zajedništva, prijateljstva ili ljubavi. Transmedijsko pripovijedanje, također poznato kao multiplatformsko pripovijedanje, tehnika je pričanja priča na više platformi i formata koji koriste tekuće digitalne tehnologije. Sa proizvodnog stajališta, to uključuje stvaranje sadržaja koji se bavi publikom koristeći razne tehnike koje prožimaju njihov svakodnevni život. Kako bi se postigao ovaj angažman, transmedijskom proizvodnjom će se razvijati priča na više oblika medija kako bi omogućila jedinstveni doživljaj sadržaja preko više kanala. Važno je da svi dijelovi sadržaja nisu samo povezani (otvoreno ili suptilno), već su u narativnom sinkronicitetu jedni s drugima. Od davnina su ljudi živjeli u mitovima, bajkama, a legende su komunicirali kroz usmene tradicije, kroz slike i kasnije, kroz pisane riječi. Postoji već razrađena metodologija (Salmon, 2010) koja se primjenjuje u mnogim destinacijama kao mehanizam storytellinga i „strategiju Šeherezade” u kojima su integrirane četiri funkcije:

1. prezentirati prirodnu i kulturnu baštinu kroz priču koja treba konstruirati narativni identitet mjesta (engl. storyline),

2. smjestiti priču u željeno vrijeme, upravljati ritmom i narativnom napetošću tijekom cijelog trajanja (engl. timing),

3. uokviriti poruku destinacije (engl. framing), odnosno istaknuti turističke atrakcije kao glavne turističke privlačnosti uokviriti poruku destinacije (engl. framing), odnosno istaknuti turističke atrakcije kao glavne turističke privlačnosti,

4. stvoriti mrežu na Internetu i na terenu, odnosno hibridnu i zaraznu sredinu kroz koju se privlači pažanja i strukturira poželjna tržišna niša turista (engl. networking). 
Važnost takovih interakcija u kreiranju jedinstvenog i upečatljivog doživljaja za cijelu regiju pruža priliku da obilježiti iskustvo u lokaciji. Ako su turisti transformirani kreativnim iskustvom, oni će ga nastaviti povezivati sa mjestom gdje se dogodilo. U idealnoj pripovijedanoj propagandnoj situaciji, postoji identitet između stvarnog i zamišljenog svijeta. Za medijskog proizvođača publika je postala imovina, a stvaranje mogućnosti za njihov angažman diljem medijskog spektra moćan put do cilja igre. O moći interpretacije nematerijalne baštine u kreiranju turističkog proizvoda pišu Lekić, Blajić i Franjić (2017).

Tablica u nastavku prikazuje što se sve može interpretirati u Križevcima i okolici.

Tablica 3: Potencijali za storytelling u Križevcima i okolici

\begin{tabular}{|r|l|}
\hline \multicolumn{2}{|l|}{ Što sve može biti interpretirano u Križevcima i okolici? } \\
\hline 1. & $\begin{array}{l}\text { Usmena predaja i narodna književnost (dijalekti, poslovice i izreke, } \\
\text { šale, vicevi, pjesništvo, pripovjedaštvo, pripovjedači, mitologija i } \\
\text { bajke) }\end{array}$ \\
\hline 2. & $\begin{array}{l}\text { Uprizorenje i predstave (kazalište, karneval, folklorno-turističke } \\
\text { priredbe, narodni ples, instrumenti, instrumentalni sastavi svirača, } \\
\text { narodno pjevanje, narodne pjesme, narodni pjevači izvođači, svirači } \\
\text { izvođači, folklorno-plesne skupine, putujući pjevači, likovna djela, } \\
\text { igre - dječje, odrasle i sportske) }\end{array}$ \\
\hline 3. & $\begin{array}{l}\text { Običaji i navike (godišnji običaji, običaji životnog ciklusa, radni } \\
\text { običaji, pravni običaji, proslave) }\end{array}$ \\
\hline 4. & $\begin{array}{l}\text { Znanje o okolišu (biljnome svijetu, životinjskom svijetu, vremenu, } \\
\text { vodi, prostoru, svemiru, narodnom liječenju - liječenje ljudi i } \\
\text { životinja, skidanje uroka) }\end{array}$ \\
\hline 5. & $\begin{array}{l}\text { Gospodarsko znanje (građevinska znanja i vještine, zanatska } \\
\text { znanja, majstori, zemljoradnička znanja i radne prakse, stočarska } \\
\text { znanja i radne prakse, pčelarsko znanje i vještine, vinogradarska } \\
\text { znanja i radne prakse, kolekcionarstvo, izrada opreme, alata i } \\
\text { strojeva, lovačka znanja i vještine, prehrana - svakodnevna, } \\
\text { praznična, blagdanska, radna jela) }\end{array}$ \\
\hline 6. & Kulturni prostor (mitski krajobraz) \\
\hline
\end{tabular}


Teme koje se predstavljaju i koje su izabrane zbog svoje univerzalne i arhetipske vrijednosti komuniciraju jednako s domicilnim, kao i posjetiteljima iz drugih dijelova Hrvatske te različitih zemalja Europe i svijeta. Pojedine teme se na zaigran i pristupačan način obraćaju i dječjim posjetiteljima, kako onima predškolske dobi, tako i osnovnoškolcima. Za očuvanje identiteta, ali i za daljnji razvoj i interpretaciju važni su umjetnici i kreativni ljudi, udruge i amaterske grupe koje svoju umjetničku inspiraciju nalaze upravo u svojim korijenima i identitetu, a koji bi se na različite načine trebali uključiti u tematske ture, manifestacije, događanja, izložbe, itd. ponajprije kao donatori i kazivači, ali i kao pjesnici, književnici, novinari, glumci, glazbenici, redatelji, slikari, fotografi, plesači ... Jako je značajno unaprijediti komunikacijske i jezične vještine potrebne za uspješno prezentiranje turističkoga proizvoda storytellingom, s naglaskom na poznavanje engleskog jezika i njegovih zakonitosti potrebnih za uspješnu interpretaciju sadržaja kao što sugeriraju Vidak i Resner (2018) kroz svoje istraživanje o istoj temi.

Interpretacija storytellingom može biti i digitalna. O ideju digitalizacije storytellinga pisali su Clarizia, Lombardi i Pascale (2017) koji prednosti istoga vide kroz obogaćivanje turističke destinacije i njezinih atrakcija, očuvanje lokalne kulture i ukazivanje na autentična iskustva kulturnog turizma. Digitalizacija se može, vrlo jednostavno, primijeniti i na Križevce kao turističku destinaciju. Nadalje, kako gore autori spominju mogućnosti interpretacije jela storytellingom, ujedno se nadovezuju na zanimljivo istraživanje koje su proveli Mossberg i Eide (2017) koji su istraživanjem dokazali da implementacija storytellinga u restoranima dovodi do razvoja destinacije. Radi se o istraživanju transformacije menija $\mathrm{u}$ restoranima $\mathrm{u}$ iskustvene koncepte i prostore restorana u tzv. experienceescapes (iskustveni bijeg) i vrijedi kao odličan benchmark za ovu destinaciju. Storytelling postaje integralnim dijelom komunikacijskih strategija destinacija i doprinosi promociji i diferencijaciji turističke destinacije. U kontekstu marketinga, storytelling prenosi poruku o identitetu i atributima destinacije koji uključuju kognitivni, afektivnu i konativnu (pokusnu) dimenziju (Youssef, Leicht i Marongiu, 2019) 


\section{Književni turizam}

Često su najpopularniji i najutjecajniji filmovi nastali po književnom bestselleru ili klasiku. Prije razvoja filma i televizije publika je imala pristup samo pisanim djelima. Turizam potaknut literaturom nije nov, književnost je imala utjecaj na Grand Tour 16. st. Romantičarski pisci poput Wordswortha, Keatsa, Shellya, Byrona i Rousseaua potaknuli su veliki interes za prirodu, krajolik i planine . Razlika između filmskog turizma i turizma potaknutog literaturom je u tome da, za razliku od filmskog, posjetioci književnog turizma posjećuju mjesta koja su osobno vezana za pisca (mjesto rođenja ili smrti), dok filmski turisti posjećuju prikazana mjesta ili rodna mjesta zvijezda. Iako je interes za osobnim životom filmskih zvijezda donekle sličan onome za životom pisaca, scenaristi i njihov osobni život nisu izvor interesa ili turizma.

Književni (literarni) turizam, po svojoj prirodi imanentan značenju kulture, nije izmaknuo promjenama koje su dogodile u strukturi turizma. Kao turizam posebnih interesa odgovarajući na zahtjeve tržišta nove generaciji turista, književni se turizam susreo sa izazovima interpretiranja specifične vrste baštine, do tada rezervirane uglavnom za visokoobrazovane stručnjake i mali broj iznimno zainteresiranih entuzijasta. Još od vremena antike ljudi su posjećivali grobove omiljenih i značajnih pisaca i pjesnika kao izraz poštovanja ili potrebe za inspiracijom, ali se s vremenom ta praksa proširila se i na posjete rodnim kućama, da bi na koncu kulminirala uspostavljenjem muzeja, memorijalnog doma, interpretacijskog centra ili nekim drugim vidom književnog turizma.

Kada je riječ o željama turista i razlozima njihova putovanja, gotovo uvijek dolazimo do pitanja autentičnosti. Autentičnost se neprekidno nalazi u stanju transformacije i zato uvijek iznova zahtijeva redefiniranje. Zato ne čudi da Tylor (2001) navodi da postoji onoliko različitih definicija autentičnosti koliko postoji autora koji o tome pišu. Prema teoriji konstruirane autentičnosti, književno mjesto može biti izgrađeno oko života autora ili njegova lika/mjesta događaja opisanog u romanu (Fawcett i Carmack, 2001). Bilo da je riječ o stvarnom mjestu na kojem se odvija radnja romana ili pak umjetničkoj konstrukciji prema njegovom opisu iz romana, mjesta književnog karaktera privlače brojne posjetitelje i postaju 
značajnim turističkim atrakcijama. Tipologija književnih turista razmatra razlike između dva glavna tipa turista (oni koji posjećuju mjesta koja su povezana s životom i djelom autora i oni koji posjećuju mjesta jer su povezana s fabulom djela nekog, njima omiljenog, autora), ali to čini sa zadrškom, imajući na umu da se individualne motiviranosti razlikuju od osobe do osobe. Baš zato valja navesti da književnih turista ima toliko koliko i književnih mjesta (Herbert, 2001).

O mogućnostima razvoja književnog turizma u Hrvatskoj s posebnim osvrtom na razvoj turističkog proizvoda inspiriranog životom $\mathrm{i}$ radom Petra Preradovića pisala je Lekić (2019) dok su Vidak i Bosnić (2018) analizirale karakteristike književnog turizma u Hrvatskoj (atrakcijsku osnovu, turističku ponudu i potražnju) kao i osnažujuće i restriktivne čimbenike razvoja ovakvog posebnog oblika turizma. Konstrukciju književnog mjesta iz perspektive autentičnosti predlaže Jia (2009) što je značajno za promatranje autentičnosti Križevaca kao književnog mjesta.

$\mathrm{Na}$ tragu navedenoga, autori vide priliku u sljedećim proizvodima književnog turizma u Križevcima:

a) Tematska Tura sa Ninom Vavrom i znamenitim književnicima i piscima drama i scenskih djela sa kojima se družila: Milan Begović, Miroslav Krleža, A.G. Matoš, Milan Ogrizović i Ivo Vojnović. Tu je i nezaobilazan Branko Gavella. Uporišna točka je Gradska knjižnicu kao ishodište ture i uvod. Predlažemo nekoliko ideja za performanse i radionice, svakako uključiti lokalne umjetnike i udruge i pokrenuti stalni program koji se može nuditi domaćim gostima i gostima u gradu Zagrebu uz organizirani prijevoz.

b) Tura sa Marijom Jurić Zagorkom koja je snažno povezana s Zagrebačkom županijom i s Ninom Vavrom, a posebno je interesantna njezina politička karijera kao prve žene novinarke i. M.J. Zagorka kao majstorica fabule bila bi odličan lik kroz koji bi se mogla uključiti i priča o vinskoj udruzi Pinti i barunu Kukljici koji je bio poznat po ispijanju vina i zdravicama i šalama i u njenim romanima bio je komičan lik. Tu se posebno može uključiti priča o Križevačkim šatututima kroz radionice i takmičenja u zdravicama, pričanju viceva, 
stund-up na temu vina, vino u snovima itd. Mogućnosti su velike i predlažemo da se ovaj produkcijski dio razvije unutar edukacije $s$ turističkim vodičima i animatorima gdje bi se aktivirali njihovi osobni talenti i preferencije i tako se stvorila baza likova i tematskih tura koje se mogu izvoditi tijekom cijele godine i u različitim prigodama.

Bilo bi zanimljivo kreirati i digitalne ture sukladno predloženom. Ovo su ideju istražili i razvili Carson et. al. (2013) na primjeru Queenslanda, Australije i digitalnih književnih tura za zainteresirane posjetitelje. Riječ je o digitalnim vodičima kojim se mogu koristiti posjetitelji prilikom samostalnog obilaska destinacije. Upravo ovakve samo-vođene ture bile su predmetom istraživanja MacLeoda, Hayesa i Slatera (2009) koji su analizirali postojeću literaturu koja obrađuje područje književnog turizma i književnih tura, ali su okosnicu svojega istraživanja i prijedloga modela razvoja iskustvenih književnih tura postavili na posebna iskustva i doživljaje za turiste, kao potrošače, ali istovremeno na kreatore ovakvih tura. Doprinos se ogleda upravo u razvijenom modelu prema kojem svaka destinacija, odnosno destinacijska menadžment organizacija, može doprinijeti stvaranju dodatnog iskustva književnih tura za svoje posjetitelje.

c) Kroz povezivanje s manifestacijskim i kreativnim turizmom posebno istaknuti ulogu Iliraca. Preporodni pokret je u Križevcima naišao na vrlo plodno tlo. Križevci su bili sjedište županije na čelu sa županom i ilircem Ljudevitom Bedekovićem i podžupanom Nikolom Zdenčajem. Križevci su bili nastanjeni pretežno hrvatskim pučanstvom, uspješno su se odupirali germanizaciji i mađarizaciji te su 1830. godine odlučno stali protiv uvođenja mađarskog jezika u hrvatske škole. 1832. uprava grada podržala je Gajevu molbu za izdavanje Ilirskih narodnih novina. U Križevcima su od 1836. službovali mladi ilirci, Antun Nemčić (23 godine) i Ljudevit Vukotinović (23 godine), a vrlo često su navraćali Ljudevit Gaj, Ivan Kukuljević, Mirko Bogović, Metel Ožegović, Stanko Vraz i drugi.

d) Budoar primadone Rubido - uz ključne točke kao što je Gradska knjižnica i muzej osmisliti i prostor gdje bi bio budoar primadone 
Rubido, inspiriran poznatom opernom pjevačicom i njenim djelovanjem. Prva hrvatska koncertna pjevačica i prva hrvatska operna primadona Sidonija Erdődy Rubido živjela je u 19. stoljeću te je potjecala iz nekih od najstarijih i najuglednijih velikaških obitelji Habsburške monarhije. Ona je bila prva koja se usudila zapjevati hrvatsku budnicu "Još Hrvatska ni propala" i prvu hrvatsku operu "Ljubav i zloba". I premda joj se smiješila karijera u Beču, ona se odlučila vratiti u Hrvatsku kako bi poduprla nacionalni kulturni preporod. Udala se za Antuna Rubida, a potom se pridružila inicijativi grupe Iliraca za postavljenje prve hrvatske opere. U budoaru primadone Rubido biti će mogućnost foto sessiona odnosno kostimiranja i pripreme za fotografiranje starom tehnikom (postoje digitalni aparati koji vjerno dočaravaju tehniku stare fotografije). U budoaru izložiti haljine i detalje: šešire, rukavice, lepeze, perike i rekvizite tako da se tko ne želi ne treba potpuno maskirati već koristiti samo detalje. Napraviti nekoliko foto pointova za slikanje te naplaćivati slikanje. Razmisliti da u pojedinim danima bude prisutna i „komorkinja“ koja može napraviti frizuru i našminkati, taj dio organizirati uz najavu.

e) Dodatno ponuditi i jahanje u paru tako da se uključi i lokalne jahačke klubove gdje bi se jahalo određenom rutom i slikalo . Osoba se po želji može maskirati u odjeću epohe i za tu svrhu. Sve se stavlja na Instagram i bira se naj fotografija.

O načinu kreiranja imidža destinacije i komuniciranja o novom imidžu destinacije, posebice ukoliko se destinacija odluči na razvoj književnog turizma, pisala je Fox (2008) osvrćući se na lik i djelo Marina Držića. Pritom autorica zaključuje da mnogobrojne hrvatske destinacije ne iskorištavaju mogućnosti koje im se nude razvojem književne baštine kao značajne turističke atrakcije. Vrlo slično istraživanje proveli su Busby, Brunt i Lund (2003) te utvrdili da lokalno stanovništvo zapravo prihvaća razvoj književnog turizma kao poželjnog posebnog oblika turizma u destinaciji što odgovara i istraživanju koje je provedeno na destinaciji Križevci. Nadalje, Hoppen, Brown i Fyall (2014) naglašavaju koristi koje književni turizam pridonosi razvoju brenda destinacije. 


\section{Manifestacijski turizam}

Grad Križevci može ponuditi različite manifestacije koje bi doprinijele intenzivnijem kreiranju turističkog doživljaja, uvažavajući pri tome pravila ekonomske i ekološke održivosti, a sve u suradnji s lokalnim ustanovama, udrugama i organizacijama kao nositeljima lokalnog identiteta i nositeljima storytellinga destinacije. Iako je manifestacijski turizam tumačen i kao onaj koji ostavlja i negativne posljedice na destinaciju ukoliko neodrživo upravljan odnosno nekontroliran, u ovom dijelu autori sugeriraju tzv. spori ili održivi oblik manifestacija koje nisu namijenjene masi poput velikih festivala. Ovakve manifestacije, na tragu onoga što u svojem istraživanju zapažaju O'Sullivan i Jackson (2010) mogu doprinijeti lokalnom ekonomskom razvoju Križevaca i okolice.

U nastavku slijedi nekoliko konkretnih i održivih prijedloga za nove manifestacije koje su inspirirane poviješću i bogatom resursnom osnovom Križevaca i okoline te znamenitim Križevčanima. Prijedlozi se baziraju na sličnima koje su u svojim istraživanjima istaknuli Domšić (2013). te Blešić i sur. (2014).

Tablica 4: Festival Svetog Marka Križevčanina

\begin{tabular}{|l|l|}
\hline Proizvod & Festival Svetog Marka Križevčanina \\
\hline Tržišni potencijal & Visok \\
\hline $\begin{array}{l}\text { Potencijal za } \\
\text { razvoj proizvoda }\end{array}$ & $\begin{array}{l}\text { veliki u području cijele regije, nacionalno i } \\
\text { međunarodno kroz našu dijasporu }\end{array}$ \\
\hline $\begin{array}{l}\text { Potencijalna } \\
\text { tržišta }\end{array}$ & $\begin{array}{l}\text { Križevci su grad osam crkvenih tornjeva i neprocjenjive } \\
\text { sakralne baštine, ova manifestacija može privući } \\
\text { posjetitelje iz različitih dijelova Hrvatske (natjecatelji i } \\
\text { publika). }\end{array}$ \\
\hline $\begin{array}{l}\square \text { U tjedan dana osigurati nastupe zborova sa } \\
\text { sakralnim vokalnim ili vokalno instrumentalnim } \\
\text { programom. } \\
\text { Čimbenici } \\
\text { uspjeha } \\
\text { proizvoda }\end{array}$ & $\begin{array}{l}\text { Manifestacija natjecateljskog karaktera, stručni žiri } \\
\text { dodjeljuje nagrade na kraju događanja. } \\
\text { Osmaja za natjecatelje } \\
\text { kinale festivala se nakon održavanja može u } \\
\text { dijelovima ili u cijelosti prikazati na nekoj od } \\
\text { televizija }\end{array}$ \\
\hline
\end{tabular}

Izvor: autori 
Tablica 5: Križevački murali: festival oslikavanja

\begin{tabular}{|c|c|}
\hline Proizvod & Križevački murali - Festival oslikavanja \\
\hline Tržišni potencijal & Visok \\
\hline $\begin{array}{l}\text { Potencijal za } \\
\text { razvoj proizvoda }\end{array}$ & $\begin{array}{l}\text { veliki u području cijele regije, nacionalno i } \\
\text { međunarodno }\end{array}$ \\
\hline $\begin{array}{l}\text { Potencijalna } \\
\text { tržišta }\end{array}$ & $\begin{array}{l}\text { Nastavno na postojeći mural u Križevcima koji } \\
\text { predstavlja znamenite ličnosti iz povijesti, grad može } \\
\text { koristiti taj potencijal i razviti samostalnu manifestaciju. } \\
\text { Mogućnost povezivanja sa volonterskim turizmom i } \\
\text { likovnim kolonijama i privremenim kampovima. }\end{array}$ \\
\hline $\begin{array}{l}\text { Čimbenici } \\
\text { uspjeha } \\
\text { proizvoda }\end{array}$ & $\begin{array}{l}\square \text { Osigurati veći zid u širem središtu grada namijenjen } \\
\text { umjetnicima za oslikavanje, kao i druge javne } \\
\text { površine koje Grad procjenjuje da se mogu oslikati. } \\
\square \text { Svake godine, tijekom tjedan dana, umjetnici iz } \\
\text { Hrvatske i svijeta dobivaju temu vezanu uz Križevce } \\
\text { i križevački kraj s kojom trebaju oslikati zidove i } \\
\text { dodijeljene javne prostore } \\
\square \text { Finalno otkrivanje murala rezervirano je za } \\
\text { posljednji dan manifestacije (vikend), uz prigodan } \\
\text { koncert nekog umjetnika u središtu grada i } \\
\text { dodjeljivanje nagrade najboljim radovima } \\
\square \text { Otvoren natječaj za prijave umjetnika može okupiti } \\
\text { umjetnike iz cijele države. } \\
\square \text { Otkrivanje murala može se prenositi na društvenim } \\
\text { mrežama i medijima }\end{array}$ \\
\hline
\end{tabular}

Izvor: autori 
Tablica 6: Dani Franje Markovića

\begin{tabular}{|c|c|}
\hline Proizvod & Dani Franje Markovića \\
\hline Tržišni potencijal & Visok \\
\hline $\begin{array}{l}\text { Potencijal za } \\
\text { razvoj proizvoda }\end{array}$ & $\begin{array}{l}\text { veliki u području cijele regije i Zagreba - križevački } \\
\text { književnik i filozof čija je priča potencijal za književnu } \\
\text { manifestaciju budući je osnivač Filozofskog fakulteta u } \\
\text { Zagrebu. }\end{array}$ \\
\hline $\begin{array}{l}\text { Potencijalna } \\
\text { tržišta }\end{array}$ & $\begin{array}{l}\text { Regionalno i nacionalno kroz književni turizam, } \\
\text { studente književnosti i pisce, književne kritičare, } \\
\text { nakladnike itd. }\end{array}$ \\
\hline $\begin{array}{l}\text { Faktori uspjeha } \\
\text { proizvoda }\end{array}$ & $\begin{array}{l}\square \text { U gradskoj knjižnici osigurati prostor za večernje } \\
\text { susrete književnika koji bi predstavljali svoja recentna } \\
\text { djela, ali u suradnji s drugim ustanovama osigurati } \\
\text { dodatne prostore za čitanje poezije i proze. } \\
\square \text { U produženom vikendu (četvrtak, petak, subota } \\
\text { i nedjelja) manifestacija bi okupljala pjesnike i } \\
\text { književnike iz cijele Hrvatske, kao i ljubitelje pisane } \\
\text { riječi. } \\
\square \text { Osim promocije književnosti, grad Križevci na ovaj } \\
\text { način brendirao bi se kao grad umjetnosti i } \\
\text { umjetnika, a događanje bi imalo tendenciju širenja } \\
\text { kroz godine i novu ponudu sadržaja. }\end{array}$ \\
\hline
\end{tabular}

Izvor: autori 
Tablica 7: Dani astronomije "Križevački meteorit"

\begin{tabular}{|c|c|}
\hline Proizvod & Dani astronomije "Križevački meteorit" \\
\hline Tržišni potencijal & Visok \\
\hline $\begin{array}{l}\text { Potencijal za } \\
\text { razvoj proizvoda }\end{array}$ & $\begin{array}{l}\text { veliki u području cijele regije, nacionalno i } \\
\text { međunarodno }\end{array}$ \\
\hline $\begin{array}{l}\text { Potencijalna } \\
\text { tržišta }\end{array}$ & $\begin{array}{l}\text { Udruga Perzeidi i Križevački meteorit povezana su } \\
\text { sa mnogim udrugama u zemlji i inozemstvu pa to } \\
\text { osigurava potencijalno tržište zainteresiranih amatera } \\
\text { astronoma, fizičara, geologa i svih zaljubljenika u } \\
\text { zvijezde i čisto nebo }\end{array}$ \\
\hline $\begin{array}{l}\text { Faktori uspjeha } \\
\text { proizvoda }\end{array}$ & $\begin{array}{l}\square \text { Stručni skup astronoma, fizičara, meteorologa, } \\
\text { geologa i ostalih stručnjaka i ljubitelja astronomije } \\
\text { koji bi u nekoliko dana imali prilike čuti o novim } \\
\text { istraživanjima znanstvenika iz tog područja. } \\
\square \text { Manifestacija bi bila vezana uz lokalnu priču i } \\
\text { djelovanje poznate križevačke udruge, a koja može } \\
\text { okupiti usko profiliranu publiku koja će se tih dana } \\
\text { zadržati na području Križevaca. } \\
\square \text { U okviru manifestacije organizirati promatranje } \\
\text { noćnog neba u Kalničkom kraju uz prigodne } \\
\text { gastro specijalitete i popratnu glazbu te povezati to sa } \\
\text { mitološkim turizmom jer svaka planeta i sazvježđe } \\
\text { ima i svoju mitološku pozadinu. Na taj način širi se } \\
\text { krug zainteresiranih posjetitelja. }\end{array}$ \\
\hline
\end{tabular}




\section{Zaključak}

Gledajući stavove i mišljenja lokalne zajednice razvoj turističkog proizvoda destinacije Križevci je sociokulturna praksa, što se zanemaruje kad se stvaraju univerzalni modeli kao „know-how“. Sociokulturna priroda održivog turističkog proizvoda ne ide za tim da proizvod ikada kompletira, već ga gleda kao proces koji se razvija i koji je neprekidan. Zato je prepoznavanje društvene prirode turističkog proizvoda bitno zbog lokalne zajednice, jer ona ima značajnu ulogu u kreiranju turističkih proizvoda koji su društveno i kulturno održivi.

U skladu sa mišljenjem i stavovima lokalne zajednice naglašava se da upravljački proces u okviru održivog turizma trebao bi prije svega biti po mjeri i ukusu domaćih ljudi koji žive u turističkoj destinaciji ali i u skladu s prirodom. Dok je za gospodarski razvoj općenito odgovorna lokalna vlast, uključenost stanovništva u turistički razvoj služi kako bi se održala pozornost na tome da li prijeći društveni nosivi kapacitet. Iako smjernice uvjeravaju upotrebu društveno-odgovornog razvoja turizma, ta ideja dovodi u pitanje učinak i/ili ubrzanje destinacijskoga životnog ciklusa kada su ti zadaci prioritetni. Važno je da lokalno stanovništvo potpuno razumije koristi od turizma kako bi se razvila pravilna i realna tolerancija na njegov utjecaj na zajednicu. Premda strategija suradnje u društvu može biti dobar put razvoja turizma, to je složen i težak proces. Ako suradnja i udruživanje postupno napreduju, tj. ako su svi entiteti u suglasju, tada će grad Križevci i okolna regija ostvariti sinergiju i dobiti moć za održavanje turističkih aktivnosti tako da donose koristi svima. Analiza ukazuje na činjenicu da kretanje i etos revitalizacije i transformacije još uvijek ne prožimaju cijelu lokalnu turističku inicijativu. S jedne strane, mještani, odnosno lokalno stanovništvo koji su uključeni u ta kretanja trebali bi se snažnije identificirati s mjestom i pričom kojom je prožeta turistička ponuda. S druge strane, lokalno bi stanovništvo trebalo predanije sudjelovati, ne samo u pružanju usluga posjetiteljima, nego i u turističkoj konzumaciji mjesta.

Najnovija svjetska praksa ukazuje na zaključak da razvoj turizma na nekom području može biti dugoročno održiv samo ako su prethodno stvorene $\mathrm{i} / \mathrm{ili}$ tržištu dobro iskomunicirane vlastite konkurentske prednosti 
koje je teško ili nemoguće imitirati. U tom smislu, cijela regija, a uzimajući u obzir sve strateške potencijale kojima raspolaže, treba: a) kreirati, a nakon toga i b) komunicirati te c) dugoročno održavati svoje unikatne konkurentske prednosti. Generalno gledano, konkurentske prednosti mogu se razvijati na dva načina:

1. da se radi bolje ili jeftinije od onog što rade konkurenti,

2. da se radi na drugačiji način nego što to čine konkurenti (diferencijacija).

S obzirom da na svijetu ne postoje dvije turističke destinacije $s$ jednakim privlačnim potencijalom i/ili strukturom svoje resursnoatrakcijske osnove, $s$ identično komponiranom strukturom destinacijskog tzv. turističkog lanca vrijednosti, odnosno s istovrsnom paletom turističkih iskustava i/ili doživljaja koji je na toj osnovi moguće ponuditi, diferencijacija je znatno prihvatljiviji i jednostavniji način izgradnje destinacijskih komparativnih prednosti. To se odnosi ne samo na jezgru grada Križevaca već i na cijeli prostor regije i na pojedina njena karakteristična uža područja. S obzirom na činjenicu da primjeri drugih zemalja upućuju na zaključak da je na međunarodnom tržištu lakše uspjeti ako se u razvoj krene fokusirano, organizirano i postupno, savjetuje se da se u razvoju posebnih oblika turizma treba maksimalno podržavati razvoj onih turističkih proizvoda koji će jamčiti da će na najbrži način i uz najmanje napore moći izgraditi najizrazitije konkurentske prednosti, odnosno kod kojih će biti u stanju potencijalnim gostima ponuditi najupečatljivija iskustva i/ili doživljaje. Kulturni turizam zasigurno zauzima vodeće mjesto u paleti proizvoda koje ova destinacija može nuditi. Zbog toga se predlažu inovativni turistički proizvodi književnog i manifestacijskog turizam i implementacija storytellinga u razvoju inovativnih turističkih doživljaja. Može se reći da su sveobuhvatnija znanstvena istraživanja u području književnog turizma u Hrvatskoj nedostatna, a potencijali razvoja istoga veliki.

U tom smislu, prvi korak prema razvoju grada Križevaca i okolice kao turističke destinacije za posebne oblike turizma je kreiranje predloženih kulturno-turističkih proizvoda te stvaranje percepcije o tim turističkim 
proizvodima. Nužno je definirati sustav raspoloživih turističkih iskustava koji će potencijalnim posjetiteljima biti dovoljno privlačni da izaberu upravo Križevce i okolicu, a ne neku drugu konkurentsku destinaciju. To se može učiniti suradnjom interesnih dionika i suradničkim radom na brendiranju destinacije kao destinacije kulturnog turizma s naglaskom na odabrane posebne oblike i doživljaje. Posebno važnu ulogu u ovom procesu imat će destinacijski menadžment. Pored navedenoga, predlaže se edukacija kreatora turističke ponude, posebice u području književnog turizma, zbog iznimne atrakcijske osnove i potencijala ove destinacije za razvoj ovog posebnog oblika turizma.

Turizam grada Križevaca i okolne regije s kojom je organski povezan, izrasta zapravo iz prirodne osebujnosti i cjelokupnog kulturnog, duhovnog i tradicijskog nasljeđa. U skladu s time, i grad Križevci i cijela regija treba ostati vjerna svojim „temeljnim“ vrijednostima i svjedočiti vjernost prema vlastitoj kulturnoj tradiciji. Cijela regija može se razviti u zajedničku turističku destinaciju koja će biti onoliko autentična, koliko odražava svoju kulturnu tradiciju, tj. koliko pojedini dionici kao nositelji turističke i i kulturne djelatnosti te turistički radnici, vodiči i animatori vjerno reprezentiraju vlastitu sredinu polazeći od društvene, kulturne, umjetničke, vjerske i folklorne tradicije, tj. načina života i vrijednosti svoga kraja odnosno svoje sredine. Očuvati vlastite lokalne kulturne značajke i identitet, a istodobno pripadati globalnoj zajednici, trebao bi biti cilj. Garancija održivosti posebnih oblika turizma usko je vezana uz poticanje razvoja mikropoduzetništva i ekonomskog blagostanja.

Provedeno istraživanje ima ograničenja. Stoga se u daljnjim istraživanjima sugerira identificiranje osjećaja pripadnosti i emocionalne povezanosti ljudi s mjestom te ispitivanje autentičnosti iskustva turista (posjetitelja). Jednako tako je potrebno provesti ispitivanje posebnih osobina mjesta koje se može identificirati kao književno i odrediti mogućnosti književnog mjesta. 


\section{Literatura}

Binkhorst, E. i Den Dekker, T. (2009). Agenda for Co-Creation Tourism Experience Research. Journal of Hospitality Marketing \& Management, 18(2), 311-327.

Blešić, I. i sur. (2014). Cultural Events as a part of Cultural Tourism Development. Case Study: Sombor and Apatin (Serbia). Acta geographica Slovenica, 54(2), $381-390$.

Bosnić, I., Stanišić, J. i Tubić, D. (2014). Role of Destination Management in Strenghtening the Competitiveness of Croatian Tourism. Ekonomski vjesnik, 1, 153 - 170 .

Buhalis, D. (2000). Marketing the competitive destination of the future. Tourism Management, 21(1), 97 -116.

Busby, G., Brunt, P. i Lund, J. (2003). In Agatha Christie country:Resident perception of specialinterest tourism. Tourism, 51(3), 287-300.

Carson, S. et. al. (2013). Practices of literary tourism: an Australian case study. International Journal of Culture, Tourism and Hospitality, 7(1), 4250 .

Callot, P. (2013). Slow Tourism. U: Idowu S.O., Capaldi N., Zu L., Gupta A.D. (ur.) Encyclopedia of Corporate Social Responsibility. Springer: Berlin, Heidelberg

Capone, F. (2015). Destination management and competitiveness. Literature review and a destination competitiveness analysis. U: Capone, F. (ur.), Tourist Clusters, Destinations and Competitiveness London: Routledge.

Christou, E. (2005). Heritage and cultural tourism: A marketing-focused approach. U: Sigala, M. i Leslie, D. (ur.), International Cultural Tourism. (3 - 15). Oxford: Butterworth-Heinemann.

Clarizia, F. et. al. (2017).) An Ontological Digital Storytelling to Enrich Tourist Destinations and Attractions with a Mobile Tailored Story. U: Au M., Castiglione A., Choo KK., Palmieri F., Li KC. (ur.) Green, Pervasive, and Cloud Computing. GPC 2017. Lecture Notes in Computer Science, vol 
10232. Springer, Cham

Crouch, G. i Ritchi, B. (2000). Tourism, competitiveness and societal prosperity. Journal of Business Research, 44, 137-152.

Csapo, J. (2012). The Role and Importance of Cultural Tourism in Modern Tourism Industry. U: Kasimoglu, M. (ur.), Strategies for Tourism Industry Micro and Macro Perspectives. Books. (201 - 232). IntechOpen, Broj 2222, July.

Destinet (2020). Destination Management. Dostupno na: https://estinet. eu/topics/destination-management-good-governance (pregledano: 28. svibnja 2020.)

Domšić, L. (2013). Cultural Heritage and Identity in the Contemporary Tourism Development, 1(1).

Dredge, et. al. (2018). Digitalisation in Tourism. In-depth analysis of challenges and opportunities.Final Report. GRO-SME-17-C091-A. Dostupno na: file://C:/Users/Korisnik/AppData/Local/Temp/ REPORT\%20TourismDigitalisation\%20131118_REV\%20KB\%20EM.pdf (pregledano: 15. srpnja 2020.)

Dwyer, L. (2015). Globalization of tourism: Drivers and outcomes. Tourism Recreation Reserach, 40(3), 326-339.

Dwyer, L. i Kim, C. (2010). Destination Competitiveness: Determinants and Indicators. Current Issues in Tourism, 6(5), 369 - 414.

European Commission (2012). EU tourism trends report (April 2018)

European Commission (2020a). Internal Market, Industry, Entrepreneurship and SMEs. Cultural Tourism. Dostupno na: https:// ec.europa.eu/growth/sectors/tourism/offer/cultural_en (pregledano: 12 . ožujka 2020.)

European Commission (2020b) Mercato interno, industria, imprenditoria e PMI. Dostupno na: https:/ec.europa.eu/growth/sectors/fashion_it (pregledano: 12. ožujka 2020.)

EUROPA NOSTRA (2019). Winners of the destination of Sustainable Cultural Tourism Awards 2019 announced. Dostupno na: https://www. 
europanostra.org/winners-of-the-destination-of-sustainable-culturaltourism-awards-2019-announced/ (pregledano: 12. srpnja 2020.)

Fawcett, C. i Cormack, P. (2001). Guarding authenticity at literary tourism sites. Annals of Tourism Research, 28(3), 686-704.

Fox, R. (2008). Marin Držić: A Case for Croatian Literary Tourism. Journal of Heritage Tourism, 3(2), 138-153.

Franch, M. i Martini, U. (2002). Destinations and destination management in the Alps: A proposal for a classification scheme in the light of some ongoing experiences. Paper presented at meeting "Territoires et marchés 2ème colloque de recherche en tourisme de l'Association française des IUP Tourisme, Hôtellerie et Loisirs", Université de Savoie, Site de Chambery (F), 12-14 settembre.

Golja, T. i Slivar, I. (2014). The Importance of Measuring Sustainability in Reaching Higher Destination Competitiveness, Proceedings of the 10th European Conference on Management, Leadership and Governance ECMLG / Grozdanić, V. (ur.).

Zagreb: VERN' University of applied sciences, 2014. str. 100-110

González-Reverté, F. (2019). Building Sustainable Smart Destinations: An Approach Based on the Developmentof Spanish Smart Tourism Plans. Sustainability, 11(6874), 1 - 24.

Herbert, D. T. (2001). Literary Places, Tourism and the Heritage Experience. Annals of Tourism Research, 28(2), 312 - 333.

Hoppen, A., Brown, L. i Fyall, A. (2014). Literary Tourism: Opportunities and Challenges for the Marketing and Branding of Destinations?. Journal of Destination Marketing and Management, 3(1), 37 - 47.

Hristov, D. (2015). Tourism Versus the Visitor Economy and the Shifting Landscape of Destination Management. Tourismos, 10(1), 219-234.

HTHIC (2020) Heritage and Slow Tourism. Dostupno na: https:// heritagetourismhospitality.org/slow-tourism-2/ (pregledano: 14. srpnja 2020.)

Institut za turizam (2008). Kulturni turizam 2008. Stavovi i potrošnja 
posjetitelja kulturnih atrakcija i događanja u Hrvatskoj. Zagreb: Institut za turizam.

Institut za turizam (2015). Akcijski plan razvoja kulturnog turizma. Zagreb: Institut za turizam.

Institut za turizam (2018). Ljeto 2017. Tomas. Stavovi i ponašanje turista. Zagreb: Institut za turizam.

Jia, H. (2009). The construction of literary tourism site. Tourism: An International Interdisciplinary Journal, 57(1), 69 - 83.

Klarić, et. al. (2011). Muzeji i turizam. Djelovanje muzeja kao dionika kulturnog turizma. Priručnik. Zagreb: Muzej suvremene umjetnosti.

Lekić, R., Blajić, B. i Franjić, T. (2017). Mythical Landscape and Holy Geography in Creative Cultural Tourism. 4th International Scientific Conference ToSEE - Tourism in Southern and Eastern Europe 2017 Tourism and Creative Industries: Trends and Challenges, Opatija, Republika Hrvatska, 291-306.

Lekić, R. (2019). Tourist Route - A Trail of Authors and Poets of fhe County of Zagreb. International Journal of Euro-Mediterranean Studies, 12 (2), 4166.

MacLeod, N., Hayesa, D. i Slatera, A. (2009). Reading the Landscape: The Development of a Typology of Literary Trails that Incorporate an Experiential Design Perspective. Journal of Hospitality Marketing and Management, 18(2/3), 154-172.

Mahika, E. (2011). Currenttrends in tourist motivation. Cactus Tourism Journal, 2(2), 15-24.

McKercher, B (2002) Cultural Tourism: The Partnership between Tourism and Cultural Heritage Management. New York: Haworth Hospitality Press McKercher i Du Cros (2002). Cultural Tourism: The Partnership Between Tourism and Cultural Heritage Management. New York: Hayworth Hospitality Press.

McKercher, B and Du Cros, H (2003). Testing a Cultural Tourism Typology, The International Journal of Tourism Research, 5(1), 45-58. 
Mihajlović, i. i Koncul, N. (2016). Changes in consumer behaviour - the challenges for providers of tourist services in the destination. Economska istraživanja, 29(1), 914-937.

Milanja, C. (2012). Konstrukcije kulture. Modeli kulturne modernizacije u Hrvatskoj 19. stoljeća. Biblioteka Studije - Knjiga 16. Zagreb: Institut društvenih znanosti Ivo Pilar

Moira, P., Mylonopoulos, D. i Koundoudaki, E. (2017). The Application of Slow Movement to Tourism. Is Slow Tourism a New Paradigm? Journal of Tourism and Leisure Studies, 2(2), 1-10.

Morrison, A.M., Bruen, S.M. i Anderson, D.J. (1998). Convention and visitor bureaus in the USA: A profile of bureaus, bureau executives, and budgets. Journal of Travel and Tourism Marketing, 7(1), 1-19.

Moscardo, G. (2015). Searching for Well-being: Exploring Change in Tourist Motivation. Tourism Recreation Research, 36(1), 15-26.

Mossberg, L. i Eide, D. (2017). Storytelling and meal experience concepts. European Planning Studies, 25(7), 1184-1199.

O'Sullivan, D. i Jackson, M. J. (2010). Festival Tourism: A Contributor to Sustainable Local Economic Development? JournaL of Sustainable Tourism, 10(4), 325 - 342.

Presenza, A. i Sheehan, L. (2005). Toward The Model of The Roles and Activities of Destination Management Organizations. Dostupno na: https:// www.academia.edu/download/50282840/53fc6e0c0cf2364ccc049a1a.pdf (pregledano: 29. svibnja 2020.)

Rainette, C., Dumont, E. i Drdacky, T. (2007). Pro-active management of the Impact of Cultural Tourism upon Urban Resources and Economies. Deliverable broj 23, March, 2007. Dostupno na: http://culture-routes.lu/ picture/IMG/pdf/790_long_en.pdf (pregledano: 12. veljače 2020.)

Ritchie, J.R. B. i Crouch, G. I. (2003). The Competitive Destination, A Sustainable Tourism Perspective. Trowbridge: Cromwell Press.

Salmon, C. (2010). Storytelling: Bewitching the Modern Mind. London: Verso. 
Selen, W. i Ogulin, R. (2015). Strategic Alignment across a Tourism Business Ecosystem. Athens Journal of Tourism, 2(3), 167-178.

Silberberg, T. (1995). Cultural tourism and business opportunities for museumsand heritage sites. Tourism Management, 16(5), 361-365.

Slivar, I. (2018). Stakeholders in a Tourist Destination - Matrix of Possible Relationships Towards Sustainability. Open Journal for Research in Economics, 1(1), 1-10.

Slivar, I. i Golja, T. (2015). Europsko turističko tržište i trendovi razvoja. Pula: Sveučilište Jurja Dobrile u Puli.

Tigu, G. (2012). New Challenges for Tourism Destination Management in Romania. U: Kasimoglu (ur.) Strategies for Tourism Industry Micro and Macro Perspectives. (167 - 184) Dostupno na: https://www. intechopen.com/books/strategies-for-tourism-industry-micro-and-macroperspectives (pregledano: 15. srpnja 2020.)

Tylor, J. P. (2001). Authenticity and sincerity in tourism. Annals of Tourism Research, 28(1), 7-26.

UNESCO (2001). Univerzalna deklaracija UNESCO-a o kulturnoj raznolikosti. Dostupno na: http://www.unesco.org/new/fileadmin/ MULTIMEDIA/HQ/CLT/diversity/pdf/declaration_cultural_diversity_ hr.pdf (pregledano: 12. ožujka 2020.)

UNWTO (2007) A Practical Guide to Tourism Destination Management. Madrid: UNWTO

UNWTO (2018). Tourism and Culture Synergies. Madrid: UNWTO

UNWTO (2019). UNWTO Guidelines for Institutional Strengthening of Destination Management Organizations (DMOs) - Preparing DMOs for new challenges. Madrid: UNWTO

Vodeb, K. (2012). Service sector in terms of changing environment. Competition in tourism in terms of changing environment. Procedia Social and Behavioral Sciences, 44, 273-278.

Vidak, I. i Bosnić, I. (2018). Literary Tourism in Croatia. 28th International Scientific Conference on Economic and Social Development, Pariz, 2018., 
$277-282$

Vidak, I. i Resner, M. (2018). Važnost storytellinga u turizmu kao komunikacijske i jezične vještine. 4. međunarodni kongres o ruralnom turizmu, Zbornik radova, 299-307.

Zakon o turističkim zajednicama i promicanju hrvatskog turizma, Narodne novine 52/19 i 42/20

Yousaf, A., Amin, I., Santos, J. A. C. (2018). Tourist's Motivations to Travel: A Theoretical Perspective on the Existing Literature. Tourism and Hospitality Management, 24(1), 197-211.

Youssef, K. B., Leicht, T. i Marongiu, L. (2019). Storytelling in the context of destination marketing: an analysis of conceptualisations and impact measurement. Journal of Strategic Marketing, 27(8), 696 - 713.

\section{Summary}

Competitiveness of tourist destinations is defined as its ability to create and successfully integrate tourist products, i.e. services and experiences of more added value. The development of destination management and strategic positioning through selected tourist products, i.e experiences, and management of both the value chain on the one hand, and the experience of visitors on the other, are preconditions for sustainable tourism development. The tourist product is formed primarily at the destination level, and partly at the regional level, which makes regions and (more recently) destinations a means of exchange, i.e. what is offered and sold on the tourist market. Therefore, the process of managing tourist destinations today, although largely a virtual and nonstandardized, is becoming not only important but also a necessary activity and a prerequisite for competitive and sustainable tourism growth in destination - regardless of its size.

The purpose of this research is to determine the opportunities for the development of cultural tourism products in Križevci. Primary research was conducted in Križevci - focus groups and online survey. The resource base of the destination is observed. The goal is twofold. The primary aim 
is to encourage the development of innovative cultural tourism products based on the attraction base of the destination. Secondarily, authors want to point to opportunities for improvement, especially the importance and role of destination management in the development of attractiveness factors that strongly affect the destination competitiveness. The paper establishes a link between the theoretical definition of the concept of cultural tourism and destination management and the results of empirical research. Results indicate that residents recognize the potential of cultural resources of Križevci for development of cultural tourism products. However, there is a strong gap between the current cultural tourism offerings and the possibilities this destination has based on its main highly attractive resources. Therefore, authors propose several innovative cultural tourism products that could be integrated in the current destination's offerings.

Results of the study are useful for destination planners and managers as well as to other interested stakeholders in tourism that are willing to contribute to development of cultural tourism in this destination (in particular: literary and festival tourism). However, locals that wish to be included in creative interpretation of intangible heritage can also benefits from the research results as well as authors observations and creative proposals.

Key words: destination management, cultural tourism, literary tourism, storytelling, festival tourism, Križevci. 